\title{
ANALISIS AKAD NIKAH VIA TELECONFERENCE MENURUT FIQIH MAZHAB DAN HUKUM POSITIF INDONESIA
}

\author{
Wardah Nuroniyah \\ Fakultas Syariah dan Ekonomi Islam \\ IAIN Syekh Nurjati Cirebon \\ Jl. Perjuangan By Pass Sunyaragi Cirebon \\ Email :wardah.faza@yahoo.com
}

\begin{abstract}
Abstrak
Akad nikah melalui media komunikasi teleconference merupakan salah satu bentuk akomodasi kepentingan masyarakat, akad nikah semacam ini merupakan suatu alternatif pilihan efektif dan efesien (dengan tidak meninggalkan syariat Islam) bagi masyarakat modern. Dalam UUP 1974 maupun PP No. 9 Tahun 1975 hanya diatur tentang sahnya pernikahan yang dilaksanakan berdasarkan agama dan kepercayaannya, yakni sebagaimana yang diatur dalam Pasal 2 ayat (1) UUP 1974, lebih lanjut pernikahan tersebut harus dicatatkan ke Kantor Pencatatan Pernikahan (Pasal 2 ayat (2) Jo. Pasal 2 ayat (1) PP No. 9 Tahun 1975. Sedangkan dalam fiqih, penerapan syarat dan rukun nikah mempunyai sebuah landasan dan alasan yang rasional dan transanden untuk dilaksanakan. Setiap penetapan syara'harus diikuti dengan berbagai macam alasan, baik dari sisi manfaat, madlarat (dampak negatif), juga hal-hal lain seperti setting social historis yang ada waktu itu. Berkaitan dengan akad nikah via teleconference, ada beberapa point dalam syarat dan rukun nikah yang harus dianalisa yang jika diterapkan bisa menjadi perdebatan. Dengan menggunakan pendekatan normatif, analisis akad nikah via teleconference baik menurut fiqih mazhab dan hukum positif Indonesia,dapat dikaji argumentasi hukumnya. Jika diukur dengan hasil ijtihad para ulama terdahulu, khususnya Imam mujtahid yang empat, ternyata akad nikah via teleconfrence itu memang dapat saja dilaksanakan dengan syarat-syarat tertentu dan dalam keadaan tertentu. Dalam konteks ini berarti akad nikah melalui teleconfrence itu tidaklah dapat dikatakan sah begitu saja, akan tetapi bersifat kasuistis sesuai dengan situasi yang sedang dihadapi.
\end{abstract}

Kata Kunci; Akad Nikah, Teleconfrence, Majlis Akad, Saksi dan Pencatatan

\begin{abstract}
Marriage through teleconference communication media is one form of accommodation of public interest, this kind of marriage contract is an alternative effective and efficient choice (by not leaving Islamic sharia) for modern society. In the UUP 1974 and PP no. 9 of 1975 is stipulated only on the validity of marriages which are conducted on the basis of their religion and belief, namely as provided for in Article 2 paragraph (1) of the UUP 1974, further the marriage shall be registered at the Marriage Registration Office (Article 2 paragraph (2) of Jo. Paragraph (1) of Government Regulation No. 9 of 1975. Whereas in fiqh, the application of the terms and principles of marriage has a rational and transparent basis and reason to be implemented. Each determination should be followed by various reasons, Negative impact), as well as other things like the historical social setting that existed at that time. In connection with the marriage contract via teleconference, there are several points in the terms and pillars of marriage that must be analyzed which if applied can be a debate. Using normative approach, Marriage via teleconference both according to jurisprudence and positive law of Indonesia, can be studied the legal argument. If measured by the results Ijtihad of the previous scholars, especially the four mujtahid Imam, the marriage contract via teleconfrence can indeed be carried out under certain conditions and under certain circumstances. In this context means the marriage contract through teleconfrence can not be said to be legal, but it is casuistic in accordance with the situation at hand.
\end{abstract}

Keywords; Akad Nikah, Teleconfrence, Majlis Akad, Witness and Recording 


\section{A. Pendahuluan}

Di dalam masyarakat yang dinamis, selalu terjadi berbagai perubahan, termasuk berkembangnya penggunaan ungkapan-ungkapan tertentu secara menyimpang dari pengertian aslinya. Dalam aneka tindakannya, subyek hukum tidak akan lepas dari adat atau 'urf yang berlaku secara mapan di masyarakatnya. Oleh karena itu, dalam penerapan hukum di tengah-tengah masyarakat, keberadaan 'urf atau adat perlu diperhatikan, perilaku dan pernyataan-pernyataan hukum seseorang haruslah dianggap terikat dengan kebiasaan semasa dan setempat. ${ }^{1}$ Untuk itu perkembangan di segala lini kehidupan masyarakat mendorong masyarakat untuk lebih peka terhadap segala sesuatunya. Demikian juga dengan agama, ia dituntut untuk fleksibel dan mengakomodasi segala sesuatunya. Sebagai umat Islam kita dituntut untuk terus menggali dan mengembangkan ajaran yang fleksibel (peka jaman) agar semakin terbukti bahwa syari'at Islam itu memang cocok dengan fitrah kemanusiaan (rahmatan lil 'alamin).

Teknologi komunikasi khusunya pada teleconference merupakan sebuah media penghantar dari maksud seseorang dalam melakukan berbagai hal dalam kehidupan sehari-harinya yang sudah mendapatkan

${ }^{1}$ Lahmuddin Nasution, Pembaharuan Hukum Islam dalam Mazhab Shafi $i>$ (Bandung: Remaja Rosdakarya, 2001), 155. legitimasi di mata publik sebagai alat penghubung bukan inti perbuatannya tetapi sebagai medianya. Akad nikah melalui media komunikasi teleconference merupakan salah satu bentuk akomodasi kepentingan masyarakat dalam konteks fiqih sebagai wujud dari kepekaan syariat Islam dalam menghadapi tantangan dan perkembangan zaman. Dan selama nilai kemanfaatan dan kemaslahatan tercapai dalam hal ini dengan tidak menafikan unsur kemadlaratan yang mungkin terjadi, maka hal akad nikah semacam ini merupakan suatu alternatif pilihan efektif dan efesien (dengan tidak meninggalkan syariat Islam) bagi masyarakat modern.

\section{B. Sejarah}

Perkembangan

\section{Teleconference}

Perkembangan teknologi dan ilmu pengetahuan (knowledge) dari hari kehari semakin menggembirakan, banyak ditemukan teknologi-teknologi baru dibidang komunikasi, sebagai contohnya adalah internet, telepon, teleconference, handphone, telegram, telegrap, pager, HT (Handy Talky), faximile dan lain sebagainya.

Wartel, warnet, dan teleconference tumbuh berkembang bagaikan jamur dimusim semi. Sehingga tidak heran jika media komunikasi semacam ini kini mulai sangat akrab dan kental dengan aktivitas kehidupan masyarakat kita sehari-hari. 
Mulai dari kativitas pergaulan, pemberitaan, jual beli, lelang, perjanjian, hiburan, bisnis hingga mengilhami pemikiran beberapa orang untuk melakukan akad nikah. ${ }^{2}$

Adapun Asal-usul internet dimulai tanggal 4 Oktober 1957 ketika Uni Soviet meluncurkan bulatan yang mengeluarkan suara "bip", diberi nama Suptik, mengelilingi orbit. $^{3}$ Setelah itu Amerika yang waktu itu dijabat oleh presiden Dwight D (presiden Amerika ke 34) meluncurkan ARPA (the advanced research projects agency) sebagai jawaban atas perang pengaruh dengan Uni Soviet. Sementara fasilitas World Wide Web mulai dirajut antara bulan Maret 1989 sampai bulan November 1990. Pelopornya adalah Tim Berners Lee. Teknologi nirkabel (internet), sebenarnya sudah ditemukan pada abad ke-19, namun baru abad ke-21 bisa dimaksimalkan. Digitalisasi dan protokol-protokol internet membuat teknologi ini bisa mengusung data lebih banyak sesuai keinginan. Pada pertengahan tahun 2000 sebagian orang Eropa dan Amerika memiliki telepon seluler selain mobil dan komputer pribadi (PC). Business Wire mencatat hanya 40\% anak muda Amerika yang memiliki akses

\footnotetext{
${ }^{2}$ Sahal Mahfudz, Solusi Problema Umat (Surabaya: Ampel Suci, 2003), 237.

${ }^{3}$ John Naughton, A Brief History of the Future, editor, Lyndon Saputra, Sejarah Singkat dari Masa ke Masa Depan (Asal Usul Internet), Terj. (Batam Centre, 2004), 121.
}

ke internet (di PC-nya), tetapi $100 \%$ dari Amerika memiliki telepon seluler. ${ }^{4}$

Di Indonesia penyelenggaranan media telekomunikasi sudah mempunyai aturan tertentu, dalam PP No. 52 tahun 2000 tentang penyelenggaraan Telekomunikasi, internet dimasukkan ke dalam jenis jasa multimedia yang didefinisikan sebagai penyelenggaraan jasa telekomunikasi yang menawarkan layanan berbasis teknologi informasi. Undang-undang No. 36 tahun 1999 tentang Telekomunikasi, yang baru mulai berlaku tanggal 8 September 2000, mengatur beberapa hal yang berkenaan dengan kerahasiaan informasi, antara lain pasal 22 yang menyatakan bahwa setiap orang dilarang melakukan perbuatan hak, tidak sah atau memanipulasi (a) akses ke jaringan telekomunikasi dan atau (b) akses ke jasa telekomunikasi dan atau (c) akses ke jaringan telekomunikasi khusus. Bagi pelanggaran ketentuan tersebut diancam pidana penjara maksimal 6 tahun dan atau denda maksimal 600 juta. $^{5}$

Kemudian pasal 40 menyatakan bahwa setiap orang dilarang melakukan penyadapan atas informasi yang disalurkan melalui jaringan telekomunikasi dalam bentuk apapun.

\footnotetext{
${ }^{4}$ Budi Putra, Planet Seluler (Tangerang: Logicom Publications, 2004), 16.

${ }^{5}$ Republik Indonesia, Undang-Undang No. 36 Tahun 1999 tentang Telekomunikasi (Kalibening: Pustaka Digital, SMP alternatif Qaryah Thoyyibah, 2005), 10.
} 
Bagi yang melanggar ketentuan tersebut diancam pidana penjara maksimal 15 tahun penjara. ${ }^{6}$ Undang-undang telekomunikasi juga mengatur kewajiban penyelenggara jasa telekomunikasi untuk pelanggan jasa telekomunikasi melalui jaringan telekomunikasi dan atau jasa telekomunikasi yang diselenggarakannya (pasal 42 ayat 1). Bagi penyelenggara yang melanggar kewajiban tersebut diancam pidana penjara maksimal 2 tahun dan atau denda maksimal rp. 200 juta. Namun begitu penyelenggara jasa telekomunikasi wajib merekam informasi tersebut, serta dapat memberikan pidana atas permintaan tertulis Jaksa Agung dan atau Kepala Kepolisian RI untuk tindak pidana tertentu, yaitu tindak pidana yang diancam dengan pidana penjara selama 5 tahun ke atas, seumur hidup atau mati. Permintaan dapat juga diajukan oleh penyidik untuk tindak pidana tertentu sesuai dengan Undang-undang yang berlaku, seperti misalnya tindak pidana yang sesuai dengan undang-undang Psikotrapika, undang-undang tindak pidana korupsi dan sebagainya.

Undang-undang no. 39 Tahun 1999 tentang HAM juga mengatur secara khusus mengenai kerahasiaan informasi. Pasal 32 Undang-undang HAM menyatakan bahwa kemerdekaan dan

\footnotetext{
${ }^{6}$ Republik Indonesia, Undang-Undang No. 36 Tahun 1999 tentang Telekomunikasi, 16.
}

rahasia dalam hubungan surat-menyurat termasuk hubungan komunikasi melalui sarana elektronika tidak boleh diganggu, kecuali atas perintah hakim atau kekuasaan lain yang sah sesuai dengan ketentuan peraturan perundangundangan. $^{7}$

Adapun Teleconference secara istilah adalah berasal dari bahasa Inggris yang diartikan " A teleconference is a telephone meeting among two or more participants involving technology more sophisticated than a simple two-way phone connection". (merupakan telepon meeting antara dua orang atau lebih peserta yang menggunakan teknologi tinggi demi kenyamanan orang-orang yang berhubungan). ${ }^{8}$

Disela-sela perkembangan internet dan telepon, lahirlah penemuan baru yang menggabungan antara televisi dan telepon yang disebut Teleconference. Dengan media ini komunikan (orang yang berbicara) dapat menyampaikan pesannya kepada recipient (lawan bicara) tanpa hanya mendengarkan suara (audio) tapi juga bisa melihat fisiknya (visual). Dengan segala bentuk kecanggihan dan fasilitas dari teknologi ini, customer (konsumen) dapat berkomunikasi dengan model apapun yang diinginkan seperti

\footnotetext{
${ }^{7}$ Republik Indonesia, Undang-Undang No. 36 Tahun 1999 tentang Telekomunikasi, 16.

${ }^{8} \mathrm{http}: / /$ searchnetworking.Techttarget.com/s Definition/0,,sid7_gci213111,00.html.
} 
berhadapan langsung, sekaligus menyimpan data-data yang dianggap penting.

\section{Analisis Pernikahan via Teleconference dalam Fiqih Mazhab}

\section{Syarat dan Rukun Pernikahan}

Akad nikah adalah didasarkan atas suka sama suka, atau rela sama rela. Oleh karena perasaan rela sama rela itu adalah hal yang tersembunyi, maka sebagai manifestasinya adalah ijab dan qabul. Oleh karena itu, ijab dan qabul adalah unsur mendasar bagi keabsahan akad nikah. Ijab diucapkan oleh wali sebagai pernyataan rela menyerahkan anak perempuannya kepada calon suami, dan qabul diucapkan oleh calon suami, sebagai pernyataan rela mempersunting calon isterinya. Lebih jauh lagi, ijab berarti menyerahkan amanan Allah kepada calon suami dan qabul berarti sebagai lambang bagi kerelaan menerima amanah Allah tersebut. Dengan Ijab dan qabul menjadi halal sesuatu yang tadinya haram.

Dalam sebuah hadis yang diriwayatkan oleh Muslim, Rasulullah bersabda: "Takutlah kalian kepada Allah dalam hal wanita, mereka (perempuan) di tangan kalian sebagai amanah dari Allah, dan dihalalkan bagi kalian dengan kalimat Allah".
Yang dimaksud dengan "kalimat Allah" dalam hadis tersebut ialah ucapan ijab dan qabul. Oleh karena demikian penting arti ijab dan qabul bagi kebsahan akad nikah, maka banyak persyaratan secara ketat yang harus dipenuhi untuk keabsahannya. ${ }^{9}$

Penerapan syarat dan rukun nikah mempunyai sebuah landasan dan alasan yang rasional dan transanden untuk dilaksanakan oleh umat manusia. Sebagaimana yang kita tahu, bahwa setiap penetapan syara', maka disitu akan diikuti dengan berbagai macam alasan, baik dari sisi manfaat, madarat (dampak negatif), juga hal-hal lain seperti setting social historis yang ada waktu itu. Berkaitan dengan akad nikah via teleconference, hanya ada beberapa point dalam syarat dan rukun nikah yang ketika diterapkan dalam prosesi akad nikah tersebut menjadi perdebatan, antara lain:

\section{Saksi}

Jumhur ulama sepakat menyatakan syahadah (kesaksian) merupakan syarat nikah, tetapi mereka berselisih pendapat mengenai apakah kesaksian itu merupakan syarat sahnya akad nikah atau hanya merupakan syarat tammam. Sedangkan Abu Saur dan satu jama'ah berpendapat,

9 Satria Effendi M. Zein, Problematika Hukum Keluarga Islam Kontemporer, Analisis Yurisprudensi dengan Pendeketan Ushuliyah, (Jakarta: UIN Jakarta dan Balitbang DEPAG RI, 2004), 3. 
kesaksian sama sekali bukanlah

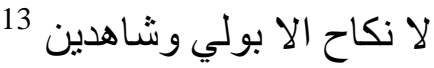
merupakan syarat sah dan bukan pula syarat tammam (sempurna). Pendapat seperti ini dalam praktek telah dilakukan oleh Hasan ibn Ali, diriwayatkan darinya bahwa ia telah melaksanakan nikah tanpa saksi, akan tetapi ia umumkan kemudian bahwa ia telah menikah. ${ }^{10}$ Kendati demikian, mereka sependapat bahwa nikah sirri (tidak dipersaksikan) tidak sah. Pangkal tolak perselisihan para fuqaha tentang masalah kesaksian ini adalah perbedaan anggapan mereka dalam menghadapi hadis-hadis yang berkenaan dengan masalah kesakisan ini. Terlepas dari adanya polemik tentang hal ini, penulis cenderung kepada pendapat jumhur yang memandang kesaksian sebagai syarat sahnya akad nikah. Selain mengamalkan hadis-hadis yang menyuruh adanya saksi juga mengamalkan hadishadis yang menganjurkan perlunya pengumuman setelah menikah kepada orang banyak. $^{11}$

Berkaitan dengan penetapan dua orang saksi dalam akad nikah, berdasarkan hadis yang diriwayatkan oleh Imam Ahmad yang berbunyi: ${ }^{12}$

${ }^{10}$ Ibn Rusyd, Bidayatul Mujtahid, (Mesir: Mustofa al-babiy, 1960), II: 17.

11 Chuzaimah T. Yanggo dan Hafidz Anshary AZ, Problematika Hukum Islam Kontemporer (Jakarta: Pustaka Firdaus, 1994), 85.

${ }^{12}$ Muhammad ibn Isma'il Amir al-Yaman al-San'ani, Subul al-Salam Sharh\} Bulugh alMaram, Cet. III (Lebanon: Dar al-Kitab al-'Arabi, 1987), no. Hadis 920, 249.

Bagi ulama yang mewajibkan adanya saksi mensyaratkan sebagai berikut:
a. Aqil Baligh
b. Merdeka
c. Islam
d. Dapat mendengar dan melihat ${ }^{14}$

Dari empat syarat saksi di atas, hanya satu yang akan kita bahas bersama yaitu syarat mendengar dan melihat. Mendengar dan melihat adalah dua komponen yang harus bersama-sama. Tidak cukup hanya mendengar suara pihak-pihak tanpa adanya wujud secara fisik. Begitu juga hanya melihat wujud fisik para pihak, namun tidak hanya mendengar suara ijab qabulnya.

Dari syarat tersebut, Syafi'iyyah sepakat menolak bahwa akad nikah yang dilakukan melalui pesawat telepon tidak sah, karena para saksi tidak melihat fisik para pihak. Hal ini karena tujuan saksi adalah mengantisipasi terjadinya persengketaan akad, dan para saksi tidak dapat diterima jika hanya mendengar suara tanpa rupa. Pendapat ini juga ditegaskan oleh Muhammad Abu Bakar Syatha, bahwa saksi harus melihat dan mendengar ijab qabul secara langsung keluar dari mulut para pihak. Alasan dari pendapat ini adalah bahwa seorang saksi

\footnotetext{
13 al-San'ani, Subul al-Salam Sharh\} Bulu>gh al-Maram, 249.

14 Sulayman al-Suwayfi, H\{ashiyat alBujayrami 'alá al-Khatib (Lebanon: Dar al-Kitab 'Arabi, tt), X: 148.
} 
harus dapat meyakini hal yang disaksikan dan tidak boleh hanya prangsaka, sebab mendengar suara tanpa melihat rupa tergolong kinayah (samar) dan tidak dapat menimbulkan suatu keyakinan dalam hati saksi.

Namun ada yang menarik dari pendapat Ibnu Hajar al-'Asqalani jika saksi meyakini bahwa yang ia dengar adalah betul suara para pihak dengan adanya indikasi-indikasi, maka hukumnya diperbolehkan. Indikasi tersebut seperti contoh ia meyakini bahwa di dalam kamar hanya satu orang bernama Zaed dikarenakan ia sendiri telah memeriksa ke dalam kamar. Kemudian ia mendengar suara dari dalam kamar tersebut dan meyakini suara itu adalah suara Zaed. Jika demikian maka kesaksian saksi dengan hanya mendengar suara di dalam kamar diperbolehkan sebab dalam benaknya ada keyakinan. $^{15}$

Dari pendapat Ibnu Hajar tersebut dapat kita tarik benang merah bahwa. Jika yang hadir dalam majelis tersebut (termasuk saksi) meyakini bahwa adanya indikasi-indikasi kuat bahwa yang sedang berbicara atau yang sedang dilihat dalam teleconfrence memang pihak yang bersangkutan, maka akad pernikahan tersebut hukumnya diperbolehkan dan sah.

15 Ibn Hajar al-'Asqalani, Fathu al-Bari, (Lebanon: Darul Kitab Arabi, tt), V: 265
Demikian juga Syafi'i, Hanafi dan Hambali sepakat bahwa pernikahan itu tidak sah tanpa adanya saksi, ${ }^{16}$ tetapi Hanafi memandang cukup dengan hadirnya dua orang laki-laki atau seorang laki-laki dengan dua orang perempuan tanpa disyaratkan harus adil. Namun mereka berpendapat bahwa kesaksian kaum wanita saja tanpa laki-laki dinyatakan tidak sah. Syafi'i dan Hambali berpendapat bahwa pernikahan harus dengan dua orang saksi laki-laki muslin yang adil. Sedangkan Maliki mengatakan saksi hukumnya tidak wajib dalam akad, tetapi wajib untuk percampuran suami terhadap istrinya (dukhul). Kalau akad dilakukan tanpa saksipun dipandang sah, tetapi bila suami bermaksud mencampuri istrinya tanpa ada saksi, akadnya harus dibatalkan secara paksa. Dan pembatalan

\footnotetext{
${ }^{16}$ Dalam Kifayat al-Akhyar: II/5:

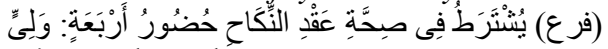

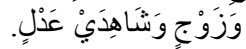

Artinya: (Cabang) dan disyaratkan dalam
} keabsahan akad nikah hadirnya empat orang ; wali,calon pengantin dan dua orang saksi yang adil. III/335

Tuhfat al-Habib 'alá Sharh al-Khatib:

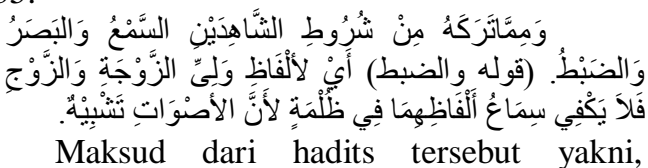
mendengar, melihat dan (dabit\}) membenarkan adalah bagian dari syarat diperkenankannya dua orang saksi. (pernyataan penyusun ' $w a-a l-d$ \} $a b t\} u$ ) maksudnya lafadz (pengucapan) dari wali pengantin putri dan pengantin pria, maka tidaklah cukup mendengar lafadz (perkataan) mereka berdua dikegelapan, karena suara itu (mengandung) keserupaan). Lihat bin/content.cgi/masail/aula/tahun_2004/nikah01.single? seemore $=y$ 
akad tersebut sama kedudukannya dengan talak ba'in. Sementara Imamiyah berpendapat bahwa kesaksian dalam pernikahan hukumnya adalah istidlal, dianjurkan dan bukan merupakan kewajiban. $^{17}$

Fungsi dan Peran saksi dalam akad nikah adalah untuk menjadi saksi sekaligus bukti atas pelaksanaan akad nikah yang jika suatu saat terjadi pengingkaran saksi bisa dipanggil untuk didengar kesaksiannya itu, selain itu juga untuk memenuhi anjuran tentang pengumuman pernikahan. ${ }^{18}$

Karena dalam akad nikah via teleconference berjauhan jaraknya dan ada beberapa pihak mungkin yang tidak bisa menyaksikan secara langsung, maka dalam hal ini saksi ditambah menjadi 4 (empat), ini didasarkan pada prinsip kehati-hatian dalam rangka menghindari kemungkinan-kemungkinan terburuk terjadi, seperti pengingkaran, penipuan, pemalsuan, penghiantan dan sebagainya. Dengan beberapa definisi di atas maka illat dari adanya saksi terpenuhi dalam akad nikah dan sudah semestinya akad nikah melalui media teleconfrence sah.

\section{Majelis Akad}

17 Muh \}ammad Jawad Mughniyah, Fiqih Lima Mazhab, Cet. II (Jakarta: Lentera Basritama, 1996), 313-314.

${ }^{18}$ Ibn Rushd, Bidayat al-Mujtahid (Mesir: Mustafa al-Babi al-Halabi, 1960), II: 18.
Akad dengan media komunikasi tentu akan berbeda dengan akad yang dilakukan secara langsung. Fuqaha sepakat bahwa akad nikah itu dilaksanakan dalam satu majelis, baik wali maupun yang mewakilinya,calon suami atau yang mewakilinya dan kedua orang saksi semuanya dapat terlibat langsung dalam pelaksanaan ijab qabul. Dari sini, maka kemudian muncul pertanyaan apakah dengan kehadiran suara, tulisan dan atau gambar (visual) saja baik ijab untuk calon suami maupun untuk wali atau yang mewakili keduanya dianggap menyimpang dari pengertian satu majelis dalam akad nikah?

Disinilah sebenarnya permaslahan pokok yang harus dipecahkan dalam menghadapi kasus akad nikah via teleconference.

Ittihadul majlis (satu majlis) bisa bermakna ittihad al-zaman (satu waktu), ittihad al-makan (satu lokasi) dan ittihad al-haiah (satu posisi). Apabila ittihad almajlis menjadi syarat sahnya jual beli, maka artinya ijab dan qabul harus berlangsung dalam waktu yang bersamaan atau hampir bersamaan, tempat yang satu dan posisi yang satu dan masing-masing muta'aqidain memahami ijab qabul lawannya. $^{19}$

19 'Alauddin al-Kasani, Bada'i al-Sana'i fi tartibi al-Syara'i, cet II, (Lebanon: Dar al-kutub al'arabi, 1982), V: 137. 
Memang Jumhur ulama secara sepakat mensyaratkan bersatunya majelis bagi ijab dan qabul. Dengan demikian apabila tidak bersatu antara majelis mengucapkan ijab dengan majelis mengucapkan qabulnya, akad nikahnya tidak dianggap sah. Pertanyaannya adalah apa yang dimaksud dengan bersatu "majelis" itu? Setelah meneliti pendapat ulama, terdapat dua penafsiran terhadap apa yang dimaksud ittihad al-majlis, yaitu sebagai berikut:

Pendapat pertama, yang dimaksud dengan ittihad al-Majlis ialah bahwa ijab dan qabul harus dilakukan dalam jarak waktu yang terdapat dalam satu upacara akad nikah, bukan didalam dua jarak waktu secara terpisah. Dengan demikian, adanya persyaratan bersatu majelis, adalah menyangkut keharusan kesinambungan waktu antara ijab dan kabul, bukan menyangkut keharusan kesatuan tempat. ${ }^{20}$

20 Pendapat ini dipegang oleh mazhab Hanafi, lihat Wahbah az-Zuhaili, al-Fiqh al-Islam wa Adillatuhu, (Beirut: Dar al-Fikr, 1986), VII: 2951.Sayid Sabiq dalam kitabnya Fiqh as-Sunnah dalam menjelaskan arti bersatu majelis bagi ijab qabul, menekankan kepada pengertian tidak boleh terputusnya antara ijab dan qabul, lihat Sayyid Sabiq, Fiqh as-Sunnah, Fiqih Sunnah jilid 6, ( Bandung: PT. Alma'arif, 1990), h. 48. Begitu juga Abdurahman al-Jaziri dalam memperjelas pengertian satu majelis dalam mazhab Hanafi adalah dalam masalah seorang lelaki berkirim surat mengakadkan nikah kepada pihak perempuan yang dikehendakinya. Setelah surat itu sampai, lalu isi surat itu dibacakan di depan wali wanita dan para saksi, dan dalam majelis yang sama setelah isi surat dibacakan, wali perempuan langsung mengucapkan penerimaannya (qabulnya). Praktik akad nikah tersebut dianggap sah dalam mazhab Hanafi, lihat Abdurrahman al-Jaziri, al-Fiqh 'ala
Pendapat kedua, pendapat yang mengatakan bahwa bersatunya majlis disyaratkan, bukan saja untuk menjamin kesinambungan antara ijab dan qabul, tetapi sangat erat hubungannya dengan tugas dua orang saksi yang menurut pendapat ini harus dapat melihat dengan mata kepalanya bahwa ijab dan qabul itu betul-betul diucapkan oleh kedua orang

Mazahib al-‘Arba'ah,.....Ibnu Qudama salah satu ahli fiqih dari kalangan mazhab Hambali dalam kitabnya al-Mughni menegaskan keabsahan kesaksian dua orang buta untuk akad nikah, dengan alasan bahwa yang akan disaksikan adalah suara. Menurutnya kesaksian orang buta dapat diterima selama ia yakin bahwa suara itu benarbenar diucapkan oleh dua orang yang melakukan akad nikah, Lihat Ibnu Qudama, al-Mughni,...... pendapat Ibnu Qudama ini diikuti oleh Sayid Sabiq dalam Fiqh as-Sunnah. Apabila diikuti berdasarkan keterangan ini maka dapat dipahami masalah esensi dari persyaratan bersatu majelis adalah menyangkut masalah keharusan kesinambungan antara ijab dan qabul. Hal ini dimaksudkan sebagai pendukung bagi kepastian bahwa ijab dan qabul itu betul-betul sebagai manifestasi dari perasaan rela dari kedua belah pihak untuk mengadakan akad nikah. Adanya jarak waktu yang memutuskan ijab dan qabul bisa jadi menunjukkan bahwa calon suami tidak lagi sepenuhnya rela untuk mengucapkan qabul dan wali nikah dalam jarak waktu itu bisa jadi sudah tidak lagi pada pendirian semula atau telah mundur dari kepastiannya. Maka untuk lebih memastikan bahwa masing-masing masih dalam kerelaannya, kesinambungan antara ijab dan qabul disyaratkan. Dan dengan demikian, maka ijab dan qabul dipandang satu kesatuan yang tidak dipisahkan, untuk itulah satu majlis dipersyaratkan dalam akad nikah. Tetapi persyaratan bersatu majlis apabila dimaksudkanhanya untuk kesinambungan waktu, maka bersatu tempat bukan satu-satunya untuk mewujudkan kesinambungan waktu. Kemudian apabila dianalisa penggabungan pendapat antara kebsahan pengucapan ijab qabul melalui surat dan keabsahan kesaksian dua orang buta, maka masalah bahwa dua orang saksi harus mampu melihat sudah tidak menjadi penting dan masalah keharusan hadir kedua belah pihak dalam satu ruangan dengan alasan dapat dilihat sudah tidak lagi dianggap menjadi syarat bagi keabsahan akad nikah. 
yang melakukan akad. Maka dari sini dapat dipahami bahwa adanya persyaratan bersatu majelis, bukan hanya untuk menjaga kesinambungan waktu, tetapi juga mengandung persyaratan lain yaitu al-mu'ayanah yaitu kedua belah pihak sama-sama hadir dalam satu tempat, karena dengan itu persyaratan dapat melihat secara nyata pengucapan ijab dan qabul dapat diwujudkan. ${ }^{21}$

Dari keterangan di atas, untuk masa sekarang dengan adanya teleconference perbedaan tempat yang disatukan dengan media komunikasi modern, membuat seolah-olah dua tempat yang berjauhan itu bisa dianggap menyatu (ta'addud almakan fi manzili al-ittihad al-makan). Pendapat yang membolehkan akad nikah via teleconference mengikuti pendapat mazhab Hanafi dalam memahami satu majelis, tetapi ada beberapa hal yang perlu diperhatiakan dalam pelaksanaannya, antara lain:

Ittihadu al-majlis dianggap berakhir apabila:
a. Alat komunikasi yang
menghubungkan muta'aqidain berakhir
b. Salah satu muta'aqidain atau keduanya berpaling (i'radl) dari ijab

${ }^{21}$ Pendapat inilah yang dipegangi mazhab Syafi'iyyah..........lihat.... c. Salah satu muta'aqidain atau keduanya berubah posisi, seperti asalnya duduk kemudian berdiri.

d. Sukutun thawilun (terdiam lama)

e. 'Urf (dalam akad kebiasaan) dianggap berakhir

f. Apabila salah satu dinatara muta'aqidain melakukan kegiatan lain, seperti makan kecuali kalau hanya sekedar satu suapan.

Berdasarkan hal di atas maka bisa disimpulkan bahwa selama kedua belah pihak yang melakukan akad melalui teleconfrence sudah saling mengenal sebelumnya itu sama dengan pelaksanaan akad dalam satu majlis. Adapun pengecekan secara fisik, maka hal itu kalau memang dianggap perlu akan dapat diatur sebelumnya dan dibuktikan lebih lanjut setelah pembicaraan via teleconfrence itu selesai. Untuk kepentingan ini misalnya dapat dilakukan dengan menetapkan saksi-saksi yang cakap bertindak sesuai dengan kebutuhan seperti diuraikan di atas.

Selanjutnya menurut pendapat yang rajih bahwa majelis akad melalui media komunikasi adalah bersifat abstrak (hukmi) dikarenakan pihak-pihak yang terlibat tidak secara langsung (fisik) dalam satu majelis. ${ }^{22}$ Oleh karena itulah majelis akad melalui media teleconfrence

${ }^{22}$ Ali Muhyidin al-Qurahdaghi, Fiqih Digital, terj. Pahruroji S, (Yogyakarta: Qanun Prisma Media, 2003), hlm 31 
diangggap ada ketika para pihak masih berkomunikasi dan masih dalam satu topik pembahasan.

\section{Ijab qabul}

Menurut pendapat para ulama mazhab bahwa pernikahan dianggap sah jika ada akad yang memuat ijab dan qabul, dan tidak dianggap sah jika hanya berdasarkan suka sama suka tanpa adanya akad. Dalam pembahasan masalah ijab qabul, para ulama mensyaratkan terhadap ijab dengan beberapa syarat, yaitu:

a. Para ulama mazhab sepakat, bahwa nikah itu sah bila dilakukan dengan menggunakan redaksi "zawajtu" atau "ankahtu" dari pihak yang dilamar atau orang yang mewakilinya, dan redaksi "qabiltu" atau radlitu" dari pihak yang melamar atau wakilnya. ${ }^{23}$ Akan tetapi para ulama mazhab berbeda pendapat tentang sah tidaknya akad nikah yang tidak menggunakan redaksi fi'il madli (menunjukkan telah) atau menggunakan lafal bukan bentukan dari kata an-nikah dan az-zawaj seperti kata hibah (pemberian), albai' (penjualan) dan sejenisnya.

Mazhab Hanafi berpendapat akad nikah boleh dilakukan dengan segala redaksi yang menunjukkan maksud

23 Muhhamad Jawad Mughniyyah, Fiqih Lima Mazhab, hlm. 309 menikah, bahkan sekalipun dengan lafadz at-tamlik, hibah, al-bai', al-atha', alibahah, dan ihlal, sepanjang akad tersebut disertai dengan qarinah yang menunjukkan arti nikah. Akan tetapi akad tidak sah jika dilakukan dengan lafadz alijarah (upah) atau al-'ariyah (pinjaman), sebab kedua kata itu tidak memberi arti kelestarian atau kontinuitas. ${ }^{24}$

b. Ijab Qabul harus dilaksanakan dalam satu majlis (pengertian satu majlis oleh Jumhur ulama difahamkan dengan kehadiran mereka dalam satu tempat secara fisik).

Pendapat ini dikeluarkan oleh ulama Malikiyyah, Syafi'iyyah dan Hanabilah, dan mereka juga beranggapan surat adalah kinayah (samar). Oleh karena itu kesaksian harus didasarkan atas

${ }^{24}$ Argumentasi mazhab tentang pemakaian shighat nikah menggunakan landasan dalil, mazhab Syafi'i akad nikah harus menggunakan lafadz zawwajtu atau ankahtu dalam bentuk madli dan tidak boleh menggunakan lafadz selain itu berargumen dengan ayat al-Qur'an al-ahzab (33): 37

$$
\text { فلما قضى زيد منها وطر ا زوجناكها }
$$

Maliki dan Hambali akad nikah dianggap sah jika menggunakan lafal an-nikah dan az-zawaj serta lafadz-lafadz bentukannya seperti al-hibah dengan syarat harus disertai menyebutkan maskawin, berargumen dengan ayat al-Qur'an surat al-Ahzab (33): 50:

Sedangkan mazhab Hanafi berpendapat akad nikah boleh dilakukan dengan sgala redaksi yang menunjukkan maksud menikah, sepanjang akad tersebut disertai dengan qarinah yang menunjukkan arti akad, mereka menggunakan dalil hadis dalam Shahih Bukhari dan Shahih Muslim dalam as-San'ani, Subulussalam, Syarh Bulughul Maram, 241:

عن ابي هريرة ان النبي ص.م قال: لرجل تزوج امراة

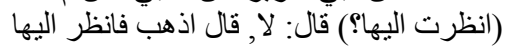


pendengaran dan penglihatan, menurut pandangan ini ijab dan kabul melalui surat tanpa mewakilkan tidak syah. Dari pemahaman di atas secara tegas dapat diketahui bahwa adanya persyaratan bersatu majelis bukan hanya untuk menjaga kesinambungan waktu, tetapi juga mengandung persyaratan lain, yaitu al-mu'ayanah kedua belah pihak samasama hadir dalam satu tempat, karena dengan itu persyaratan dapat melihat secara nyata pengucapan ijab dan qabul dapat diwujudkan. Hal yang perlu digaris bawahi dalam pandangan mazhab Syafi'i adalah bahwa masalah akad nikah mengandung arti ta'abbud yang harus diterima apa adanya. Oleh sebab itu cara pelaksanaannya adalah masalah tauqifiyyah, dalam arti harus terikat dengan pola yang telah diwariskan oleh Rasulullah saw untuk umatnya. Itulah sebabnya mengapa ijab dan qabul itu lafadznya harus seperti yang terdapat dalam nash, seperti lafadz nikah atau tazwij bukan lafadz yang lain dengan jalan qiyas. $^{25}$

Berbeda dengan Hanafiyyah, mereka memahami satu majelis bukan dari segi fisik para fihak, namun hanya hanya ijab dan qabul para pihak harus dikatakan di satu tempat dan secara berkontinyu. Dari pendapat ini Hanafiyyah memperbolehkan

\footnotetext{
${ }^{25}$ Satria Effendi, Problematika Hukum Keluarga islam kontemporer, 8.
}

akad nikah melalui surat, asalkan surat tersebut dibacakan di depan saksi dan pernyataan dalam surat segera dijawab oleh pihak-pihak.

Menurut Hanafiyyah, surat yang dibacakan di depan saksi dapat dikatakan sebagai ijab dan qabul dan harus segera dijawab. Dari pendapat Hanafiyyah tersebut, menurut KH. Sahal mahfudz dapat dianalogkan bahwa pernikahan diangap sah hukumnya dilakukan lewat media komunikasi seperti teleconference.

Sedangkan menurut pendapat yang sahih dari Syafi'iyyah, ijab qabul tidak boleh dilakukan melalui surat-menyurat. Baik ijab qabul dalam transaksi mu'amalat lebih-lebih dalam pernikahan. Mereka beralasan bahwa ijab qabul adalah suatu sarana untuk menunjukkan kedua belah pihak saling ridla akan adanya transaksi, dan ridla tidak bisa diyakinkan hanya melalui sepucuk surat. Selain itu surat tidak cukup kuat dijadikan alat bukti oleh saksi apabila telah terjadi persengketaan tentang akad tersebut. ${ }^{26}$

Solusi yang ditawarkan oleh Syafi'iyyah adalah dengan mewakilkan akad pernikahan kepada seseorang, kemudian wakil tersebut hadir dalam majelis akad pernikahan. Dalam hal mewakilkan akad para ulama sepakat bahwa transaksi yang diwakilkan

${ }^{26}$ Muhammad ibn Ahmad ibn 'Umar alShatri, Sharh al-Yaqut 'an al-Nafs, (Beirut: Dar al-Kutub al-'Arabi, tt), 356..... 
hukumnya sah. Rasulullah saw sendiri pernah mewakilkan pernikahannya kepada amr ibn Umaiyyah dan Abu Rafi' ${ }^{27}$

2. Analisis Sah dan Tidaknya Pernikahan Via Teleconfrence berdasarkan Rukun dan Syarat Pernikahan dalam Fiqih Mazahab

Diukur dengan hasil ijtihad para ulama terdahulu, khususnya imam mujtahid yang empat, ternyata akad nikah via teleconfrence itu memang dapat saja dilaksanakan dengan persyaratanpersyaratan tertentu dan dalam keadaan tertentu. Dalam konteks ini berarti akad nikah melalui teleconfrence itu tidaklah dapat dikatakan sah begitu saja, akan tetapi bersifat kasuistis sesuai dengan situasi yang sedang dihadapi.

Maka untuk menemukan hukumnya, paling tidak ada dua syarat sah nikah yang harus dibahas terlebih dahulu:

1. Calon mempelai laki-laki atau yang mewakilinya dan wali perempuan atau yang mewakilinya harus berada dalam satu majlis ketika dilangsungkan akad pernikahan.

Pertanyaannya adalah apakah dua pihak yang berbicara melalui telepon untuk melakukan transaksi dianggap dalam satu majlis, sehingga transaksi tersebut menjadi sah?. Dalam hal ini

27 Sulayman al-Suwayi, Hashiyat alBujayrami 'alá al-Khat\}ib (Beirut: Dar al-Kitab al'Arabi, tt.), X, 146.
Majma' al-fiqh telah menetapkan hukum penggunaan ponsel, HP dan internet di dalam melakukan transaksi yang isinya sebagai berikut: " Jika transaksi antara kedua belah pihak berlangsung dalam satu waktu, sedangkan mereka berdua berjauhan tempatnya, tetapi menggunakan telepon, maka transaksi antara keduanya dianggap transaksi antara dua pihak yang bertemu dalam satu majelis". ${ }^{28}$

2. Pernikahan tersebut harus disaksikan oleh dua orang atau lebih. Pertanyaannya adalah dua saksi pernikahan tersebut tidak bisa menyaksikan secara langsung akad pernikahan tersebut, mereka berdua hanya bisa mendengar suara akad vvvvv dari kedua belah pihak melalui telepon atau internet, apakah persaksian keduanya telah dianggap sah atau tidak?

Masalah tersebut mirip dengan masalah persaksian orang buta yang mendengar sebuah transaksi antara dua belah pihak, apakah persaksian orang buta tersebut sah?

Pendapat pertama, menyatakan bahwa persaksian orang buta tersebut tidak bisa diterima, ini Pendapat Hanafiyyah dan Syafi'iyyah. al-Kasani

${ }^{28}$ Majalat Majma' al-Fiqh al-Islami, OKI, Periode ke-6 (no: 2/1256). 
berkata: " persaksian orang buta tidak diterima dalam semua hal, karena dia tidak bisa membedakan antara kedua belah pihak. $^{29}$ Imam asy-Syafi'i berkata: "Jika seseorang memberikan persaksian, sedangkan dia buta dan mengatakan "saya menetapkannya, sebagaimana saya menetapkan segala sesuatu dengan mengetahui suaranya atau dengan meraba, maka persaksian orang buta tersebut tidak bisa diterima, karena suara mempunyai kemiripan satu dengan lainnya, begitu juga rabaan mempunyai kemiripan antara satu dengan yang lainnya. ${ }^{30}$

Pendapat kedua, menyatakan bahwa persaksian orang buta bisa diterima selama ia meyakini suara tersebut, ini adalah pendapat Malikiyah dan Hanabilah. $^{31}$

Pendapat ini berdalil dengan hadis Imam Bukhari yaitu Hadis dari Abdullah Ibn Umar ra, bahwasanya nabi Muhammad saw bersabda "Sesungguhnya Bilal mengumandangkan adzan pada waktu malam, maka makan dan minumlah sampai terdengar adzan Ibnu Maktum" (H.R, Bukhari)

Hadis di atas menunjukkan bahwa adzan Inu Maktum (seorang yang buta)

${ }^{29}$ Ala' al-Din al-Kasani, Badai ' al-Sana 'if Tartib al-Shara' $i$ ' (Beirut: Dar al-Kutub al-'Arabi, 1982), III: 243.

30 'Abdullah Muh\}ammad ibn Idris alShafi'i, al-Umm (Beirut: Dar al-Kutub al-'Arabi, tt.), VII: 46.

${ }^{31}$ Ala' al-Din al-Kasani, Badai ' al-Sana ' $f i$ Tartib al-Shara' $i$ ', III: 245. merupakan persaksian darinya terhadap masuknya waktu solat. Seandainya persaksian orang buta tertolak, tentunya adzannya juga tidak sah. Begitu juga yang mendengar adzan digolongkan orang buta, karena hanya mendengar suara muadzin tanpa melihat secara langsung fisik dari muadzin tersebut, dan itupun dianggap sah. (Ibnu abdul Barr, Tamhid 10/61, anNawawi: Syarh Muslim: 7/202, Ibnu Hajar: Fathul Bari; 5/265).

Dari 'Aisyah berkata: "Pada suatu ketika Rasulullah saw shalat tahajjud di rumahku, dan beliau mendengar suara Ubad yang sedang shalat di masjid, beliau bertanya "wahai aisyah apakah suara itu suara 'Ubad? Saya menjawab "benar" beliau langsung berdoa "ya Allah berilah kasih sayang kepada Ubad" (HR Bukhari).

Dua hadis di atas menunjukkan secara kuat bahwa persaksian orang buta dibolehkan dan dianggap sah dalam ibadah dan mu'amalah. Jika demikian halnya, bagaimana hukum persaksian dua orang di dalam akad pernikahan lewat telepon dan internet, apakah dianggap sah?

Orang yang menikah lewat telepon dan internet tidak lepas dari dua keadaan: Keadaan pertama: Salah satu pihak yang melakukan akad serta dua orang saksi tidak yakin dengan suara pihak kedua. Maka dalam hal ini pernikahan lewat 
telepon dan internet hukumnya tidak sah. Keadaan kedua: kedua belah pihak yang melakukan akad sangat mengenal suara antara satu dengan yang lain, begitu juga dengan dua orang saksi yakin bahwa itu suara dari pihak kedua yang melakukan akad. Pada kondisi seperti ini, persaksian atas pernikahan tersebut dianggap sah dan pernikahannya sah juga. Khususnya dengan kemajuan teknologi sehingga seseorang bisa bicara secara langsung dengan pihak kedua melalui gambar dan suara, sebagaimana yang terdapat dalam teleconfrence.

Dari pembahasan di atas yang menjadi perdebatan antara ulama adalah persaksian orang buta. Jika pernikahan itu melalui telepon tentu persaksiannya bisa disamakan dengan orang buta, akan tetapi jika pernikahan itu dilakukan melalui teleconference berarti persaksiannya bisa dilihat secara langsung dan sangat jelas serta tidak diragukan lagi, untuk itu tidak masuk persaksian yang diperdebatkan di atas, sehingga dapat ditarik kesimpulan bahwa nikah via teleconference itu sah. Untuk lebih mudahnya maka penulis mensyaratkan diperbolehkannya akad nikah via teleconference dengan alasanalasan sebagai berikut:

a. Saling kenal antara keluarga peminang dengan yang dipinang, hal ini dalam rangka meminimalisir tingkat penipuan yang tidak diinginkan.

b. Dengan media yang bisa berkomunikasi secara langsung tanpa adanya perbedaan waktu.

Di sini harus diakui bahwa teleconference merupakan di antara jenis alat yang dapat dipakai dalam komunikasi timbal balik (interactive) dan langsung (direct), sehingga modus-modus penyamaran, penipuan ataupun kejahatan lainnya dapat dicegah atau minimal di proteksi.

\section{Satu Majlis}

Jumhur ulama berpendapat bahwa akad nikah itu disyaratkan pelaksanaannya dalam satu majelis. Dalam pelaksanaan akad nikah melalui teleconfrence, syarat tersebut secara fisik jelas tidak terpenuhi. Akan tetapi tampaknya pengertian "satu majlis" menurut jumhur itu bermakna yaitu agar supaya semua pihak yang terlibat dalam akad nikah itu dapat mengikuti semua proses yang dilaksanakan, terutama dalam prosesi ijab dan qabulnya. Dengan mengikuti semua proses, maka ikatan (irtibath) yang ditimbulkan ijab dan qabul disadari dan diakui semua pihak, termasuk para saksi. Dalam akad nikah keadaan seperti itu sekaligus memang dapat dicapai, karena ijab dan qabul memang dilakukan oleh wali dan calon suami bukan saja hanya 
didengar suaranya dan shighatnya, akan tetapi secara fisik juga dapat disaksikan. ${ }^{32}$

Dalam nikah via teleconference ijab dan qabul bisa disaksikan secara fisik dengan utuh secara fisik calon suami meskipun berada ditempat yang terpisah dan bahkan dapat dikatakan "satu majlis" sesuai kriteria di atas (sesuai pengertian ittihad al-majlis). Dengan ilustrasi seperti di atas, maka dapatlah dikatakan bahwa pelaksanaan akad nikah melalui teleconfrence dengan teknik seperti itu dinyatakan sah.

\section{Ketentuan khusus saksi}

Kalau dalam ketentuan umum, kita ketahui bahwa saksi dalam akad nikah adalah dua orang, lain halnya dengan pelaksanaan nikah via teleconfrence, dalam hal ini sebaiknya melibatkan empat orang saksi yang cekatan. Dua orang dari pihak laki-laki dan dua orang dari pihak perempuan atau wali. Hal ini dimaksudkan untuk memperkaya antar pihak bahwa yang menjadi lawan komunikasi (yang berjauhan) adalah benar-benar orang yang dimaksud. Dan perlu digaris bawahi adalah saksi-saksi dalam pernikahan teleconference tidak digolongkan saksi yang buta karena mereka betul-betul bisa melihat dengan kepala sendiri, berbeda dengan saksi-saksi dalam pernikahan via telepon.

\footnotetext{
${ }^{32}$ Wahbah al-Zuhayli, al-Fiqh al-Islami waAdillatuh (Beirut: Dar al-Fikr, 1986), VII: 2951.
}

\section{Tidak dalam satu daerah atau wilayah}

Karena, hal ini akan menjadi problem sosial ketika dalam satu daerah harus dilaksanakan akad nikah via teleconfrence, selain itu ketika masih dalam satu daerah menggunakan cara ini, bukan tidak mungkin justru akan menyulut asumsi yang tidak diinginkan oleh masyarakat kepada yang bersangkutan.

\section{Analisis Pernikahan via}

Teleconference dalam Peraturan

\section{Perundang-undangan Indonesia}

Selama ini, pernikahan biasanya dilangsungkan dalam satu majelis atau satu tempat. Namun seiring dengan perkembangan teknologi komunikasi, terdapat kemungkinan dilangsungkannya pernikahan tidak dalam satu tempat, walaupun pernikahan semacam ini masih dianggap aneh oleh sebagian besar masyarakat Indonesia karena dianggap tidak wajar. Bahkan dapat menimbulkan perdebatan di antara para pakar atau aparat hukum dalam hubungannya untuk menetapkan keabsahan pernikahan memakai media telepon ataupun teleconference. Tetapi meskipun begitu pernikahan semacam ini sudah mulai sering dilakukan oleh masyarakat Indonesia. 
Pernikahan via telepon antara lain dilakukan oleh Aria Sutarto bin Drs. Suroso Darmoatmojo di Amerika Serikat (USA) dengan Nurdiani binti Prof. Dr. Baharudin Harahap di Indonesia pada tanggal 13 Mei 1989. ${ }^{33}$ Pernikahan via telepon tersebut disambungkan dengan pengeras suara dan dapat didengar oleh orang-orang yang berada di sekitarnya, disaksikan juga oleh kurang lebih 100 undangan di Jakarta, termasuk juga pejabat dari KUA Kecamatan Kebayoran Baru yang bertindak untuk mengawasi dan menyaksikan proses tersebut dan 1015 orang saksi di Amerika. ${ }^{34}$ Namun masalah yang timbul adalah pada saat dimintakan pencatatan pernikahan di buku nikah, pihak KUA setempat menolak, karena beranggapan bahwa proses ijab qabul yang dilakukan di tempat yang berjauhan atau dengan kata lain tidak terjadi pertemuan yang langsung antara kedua mempelai adalah tidak sah. Tetapi kendala untuk mendapatkan akta nikah terselesaikan ketika kasus tersebut diajukan permohonan ke Pengadilan Agama Jakarta Selatan untuk menetapkan sah dan dapat dicatatkan dan dibukukan dalam buku nikah, sesuai ketentuan yang telah diatur dalam UUP pasal 2 ayat(2) jo.

${ }^{33}$ Majalah Varia peradilan, No. 62 Th. VI 1990, 5.

${ }^{34}$ http://ahmadbinhanbal.wordpress.com/20 10/06/21/hukum-menikah-via-internet.
Pasal 2 PP No. 9/1975 mengenai pencatatan pernikahan.

Pernikahan semacam itu juga pernah terjadi pada tanggal 22 Februari 2009 antara Wafa Suhaimi di Jeddah Saudi Arabia dan Ahmad Jamil Rajab di Virginia AS yang keduanya adalah warga Indonesia. Mereka memanfaatkan cyber media untuk mendukung rangkaian ijabqabul yang dinyatakan sah oleh Syaikh Adil al-Damiri (anggota Majma' al-Fiqh al-Islami) Saudi Arabia. ${ }^{35}$

Adapun pernikahan melalui media teleconference terjadi pada tanggal 14 Desember 2004 yang dilakukan oleh Dewi Tarunawati yang berada di Bandung dan Syarif Abdurrahman Achmad di Pittsburgh AS dengan perbedaan waktu 12 jam tidak menghalangi untuk melangsungkan pernikahannya di kantor Indosat Landing Point Jln. Terusan Buah Batu Bandung yang dipimpin Petugas Pencatat Nikah (PPN) setempat. ${ }^{36}$

Urusan perkawinan di Indonesia dipayungi oleh Undang-Undang Perkawinan No. 1 tahun 1974 serta diatur ketentuannya dalam Kompilasi Hukum Islam. Saripati aturan-aturan Islam

\footnotetext{
${ }^{35}$ http://vladamirivanovic.blogspot.com/201 0/05/bm-diniyah-maudluiyah-muktamar-nu-ke32.html/

36 Idha Apriliyana, "Keabsahan Suatu pernikahan melalui Pemanfaatan Media Telekomunikasi dihubungkan Dengan penetapan pengadilan Agama Jakarta Selatan No. 1751/P/1989 tanggal 20 April 1990 mengenai Sahnya Pernikahan Melalui Telepon," Skripsi S1 Universitas Pasundan Bandung (1997), 59.
} 
mengenai perkawinan, perceraian, perwakafan dan pewarisan ini bersumber dari literatur-literatur fikih Islam klasik dari berbagai madzhab yang dirangkum dan disesuaikan dengan kebutuhan masyarakat Indonesia. Kedua dasar hukum mengenai perkawinan dan urusan keluarga tersebut diharapkan dapat menjadi pijakan hukum bagi rakyat Indonesia yang akan melaksanakan perkawinan. $^{37}$ Namun dalam praktek pelaksanaan perkawinan yang berlaku di masyarakat, ada hal-hal baru yang muncul yang bersifat ijtihad, dikarenakan tidak ada aturan yang tertuang secara khusus untuk mengatur hal-hal tersebut. Seperti pernikahan dengan jalan melalui via telpon atau sejenisnya. Padahal praktek akad nikah jarak jauh (via telepon) dengan menggunakan media teknologi ini belum pernah sekalipun dijumpai pada jaman sebelumnya. Bahkan praktek akad nikah pada jaman Nabi dan para Salafus shalih hanya mensyariatkan diperbolehkannya metode tawkil, yakni pengganti pelaku akad apabila pihak pelaku akad (baik wali maupun mempelai pria) berhalangan untuk melakukannya, dan tetap dilaksanakan dengan sepengetahuan saksi maupun kedua belah pihak yang ada. ${ }^{38}$

${ }^{37}$ Ahmad Rofiq, Hukum Islam di Indonesia (Yogyakarta:Gema Media, 2001), 102.

${ }^{38} \mathrm{bin} / \mathrm{content}$. cgi/masail/aula/tahun_2004/n ikah-01. single? seemore $=y$
Diantara Ulama yang tidak membolehkan, yaitu Munawir Syadzali, M.A Mentri Agama RI, K.H. Hasan Basri, ketua umum MUI pusat, dan prof. dr. Hasbullah Bakri, S.H. jadi, mereka dapat membenarkan tindakan kepala KUA tersebut yang tidak mau mencatat nikahnya dan tidak memberikan surat nikahnya. Dan inti alasan mereka ialah bahwa nikah itu termasuk ibadah, mengandung nilai sacral, dan nikah lewat telepon itu bisa menimbulkan confused (keraguan) dalam hal ini terpenuhi tidaknya rukun-rukun nikah dan syaratsyarat secara sempurna menurut hukum Islam. Ada ulama yang berpendapat bahwa status nikah lewat telepon itu syubhat, artinya belum safe, sehingga perlu tajdid nikah (nikah ulang) sebelum dua manusia yang berlainan jenis kelaminnya itu melakukan hubungan seksual sebagai suami istri yang sah. Adapula ulama yang berpendapat, bahwa nikah lewat telepon tidak diperbolehkan, kecuali dalam keadaan darurat. Tetapi kebanyakan ulama dan cendekiawan Muslim menganggap nikah lewat telepon itu tidak sah secara mutlak. Misalnya Komisi Bahtsul Masail Diniyyah Waqi'iyyah NU memutuskan, Pernikahan melalui alat elektronik ini tidak sah karena tidak bisa melakukan akad secara langsung. Langsung dimaksud adalah keterlibatan wali, saksi dan pengantin 
pria. Dalam akad nikah seperti ini, unsur tersebut sulit terpenuhi," kata KH Syaifuddin Amsir, ketua komisi Bahtsul Masail Diniyyah Waqi'iyyah dalam keterangan persnya, Jumat (26/3) di Asrama Haji Sudiang. Dengan alasan juga karena kedua saksi tidak melihat dan mendengar secara langsung pelaksanaan akad, dan saksi tidak hadir di majelis akad.

Selain itu, di dalam akad nikah disyaratkan lafal yang "sharih" (jelas). Pernikahan melalui alat elektronik ini tergolong "kinayah" atau samar-samar.

Berbeda dengan transaksi jual beli via elektronik. Oleh komisi dalam Muktamar ini dinyatakan sah apabila sebelum transaksi, kedua belah pihak sudah melihat dan memenuhi "mabi'" (barang yang diperjualbelikan) atau telah dijelaskan baik sifat maupun jenisnya serta memenuhi syarat-syarat dan rukunrukun jual beli lainnya. ${ }^{39}$

Adapun Tim Fatwa majelis Tarjih dan tajdid Pimpinan Pusat Muhamadiyah berpendapat bahwa pelaksanaan akad nikah melalui media komunikasi adalah sah. Dengan mengemukakan argumennya sebagai berikut; "Pada zaman dahulu, akad antara dua pihak yang berjauhan hanya terbatas melalui alat komunikasi surat atau utusan. Dewasa ini, alat

\footnotetext{
${ }^{39}$ www. INILAH.COM, Inovasi Portal Berita, web - Jumat, 26 Maret 2010| 16:14 WIB
}

komunikasi berkembang pesat dan jauh lebih canggih. Seseorang dapat berkomunikasi melalui internet, telepon, atau melalui tele-conference secara langsung dari dua tempat yang berjauhan. Alat komunikasi telepon atau hand phone (HP), dahulu hanya bisa dipergunakan untuk berkomunikasi lewat suara (berbicara) dan Short Massage Service (SMS: pesan singkat tertulis). Saat ini teknologi HP semakin canggih, di antaranya adalah fasilitas jaringan 3G. 3G atau third generation adalah istilah yang digunakan untuk sistem komunikasi mobile (hand phone) generasi selanjutnya. Sistem ini akan memberikan pelayanan yang lebih baik dari apa yang ada sekarang, yaitu pelayanan suara, teks dan data. Jasa layanan yang diberikan oleh $3 \mathrm{G}$ ini adalah jasa pelayanan video, akses ke multimedia dan lain-lain. Dengan fasilitas ini, yakni dengan video call, seseorang dapat berkomunikasi langsung lewat suara dan melihat gambar lawan bicara.

Oleh sebab itulah, jika akad ijab dan qabul melalui surat atau utusan disepakati kebolehannya oleh ulama madzhab, maka akad ijab dan qabul menggunakan fasilitas jaringan 3G, yakni melalui video call lebih layak untuk dibolehkan. Dengan surat atau utusan sebenarnya ada jarak waktu antara ijab dari wali dengan qabul dari calon suami. Sungguhpun demikian, akad melalui surat dan utusan masih 
dianggap satu waktu (satu majlis). Sedangkan melalui video call, akad ijab dan qabul benar-benar dilakukan dalam satu waktu. Dalam akad ijab qabul melalui surat atau utusan, pihak pertama yakni wali tidak mengetahui langsung terhadap pernyataan qabul dari pihak calon suami. Sedangkan melalui video call, lebih baik dari itu, yakni pihak wali dapat mengetahui secara langsung (baik mendengar suara maupun melihat gambar) pernyataan qabul dari pihak calon suami, demikian pula sebaliknya. Kelebihan video call yang lain, para pihak yakni wali dan calon suami mengetahui secara pasti kalau yang melakukan akad ijab dan qabul betul-betul pihak-pihak terkait. Sedangkan melalui surat atau utusan, bisa saja terjadi pemalsuan.

Dengan demikian akad ijab dan qabul melalui video call sah secara syar'i, dengan catatan memenuhi syarat-syarat akad ijab dan qabul yang lain, serta memenuhi rukun-rukun dan syarat-syarat sah nikah yang lain. Apabila akad ijab dan qabul melalui video call sah antara wali dengan calon suami, maka sah juga untuk akad tawkil (mewakilkan) dari pihak wali kepada wakil jika wali mewakilkan akad nikah pada orang lain. Bahkan sah juga akad ijab dan qabul melalui video call antara wakil dengan mempelai pria. ${ }^{40}$

\footnotetext{
${ }^{40}$ http://tarjihmuhammadiyah.blogspot.com.
}

Satria Effendi M. Zein sebagai salah satu pakar yang membidangi masalah hukum keluarga Islam di Indonesia ini dalam bukunya "Analisis Yurisprudensi Mengenai Masalah Keluarga Islam Kontemporer Indonesia" memberikan analisis yurisprudensi yang cukup mendalam mengenai perkawinan melalui media telepon sebagaimana dikukuhkan Putusan Pengadilan Agama Jakarta Selatan No. 1751/P/1989. Dalam pendapatnya, Satria Effendi M. Zein menyatakan bahwa ada dua macam putusan yang dapat dipilih oleh majelis hakim mengenai masalah ini, yaitu membolehkan sesuai dengan kecenderungan Madzhab Hanafi ataupun melarang sesuai dengan kecenderungan Madzhab Syafi'i. Di sini Satria Effendi M. Zein menyerahkan putusan yang diambil sesuai dengan dasar yang dipakai majelis hakim, dan memberikan penekanan bahwa keduanya boleh dipakai selama belum ada undang-undang yang secara jelas mengatur mengenai hal ini. ${ }^{41}$

Memang sebenarnya UUP 1974 maupun PP No. 9 Tahun 1975 tidak secara tegas mengatur tentang prosedur pernikahan, yang diatur hanyalah sahnya pernikahan mereka yang dilaksanakan berdasarkan agama dan kepercayaannya, yakni sebagaimana yang diatur dalam

${ }^{41}$ Satria Efendi, Problematika Hukum Islam Kontemporer, 2. 
Pasal 2 ayat (1) UUP 1974, lebih lanjut pernikahan tersebut harus dicatatkan ke Kantor Pencatatan Pernikahan (Pasal 2 ayat (2) Jo. Pasal 2 ayat (1) PP No. 9 Tahun 1975. Namun demikian apabila menyimak pasal 20 UUP 1974 dapat mengisyaratkan bahwa bagi mereka yang hendak melakukan pernikahan, seyogyanya dilakukan dalam satu tempat (satu majelis) yang sama, sehingga akan dapat diawasi, dihadiri dan diketahui secara langsung oleh Petugas Pencatat Nikah. Hal ini berkaitan dengan akan diikutinya penandatanganan Akta Nikah oleh kedua belah pihak mempelai sebagai kelengkapan administrasi.

Di dalam PP No. 9 Tahun 1975 tentang pelaksanaan UU No. 1 Tahun 1974 tentang Pernikahan telah diatur mengenai tata cara pernikahan, yaitu dalam pasal 10 yang berbunyi:

(1) Pernikahan dilangsungkan setelah hari kesepuluh sejak pengumuman kehendak pernikahan oleh Pegawai Pencatat Nikah seperti yang dimaksud dalam pasal 8 PP ini.

(2) Tata cara pernikahan dilakukan menurut hukum masing-masing agamanya dan kepercayaannya itu.

(3) Dengan mengindahkan tata cara pernikahan menurut masingmasing hokum agamnya dan kepercayaannya itu, pernikahan dilaksanakan dihadapan Pegawai Pencatat dan dihadiri oleh dua orang saksi.

Dan juga dalam pasal 11 yang berbuyi:

(1) Sesaat sedudah dilangsungkannya pernikahan sesuai dengan ketentuanketentuan pasal 10 PP ini, kedua mempelai menandatangani akta pernikahan yang telah disiapkan oleh Pegawai Pencatat berdasarkan ketentuan yang berlaku.

(2) Akta pernikahan yang telah ditanda tangani oleh mempelai itu, selanjutnya di tandatangani oleh kedua saksi dan pegawai Pencatat yang menghadiri pernikahan dan bagi yang melangsungkan pernikahan menurut agama Islam, ditandatangani pula oleh wali nikah atau yang mewakilinya.

(3) Dengan penandatanganan akta pernikahan, maka pernikahan telah tercatat secara resmi.

Oleh karena pernikahan (melalui teleconference) telah dicatat oleh Pegawai Pencatat Pernikahan pada waktu pelaksanaan ijab qabul atau akad nikah, 
namun hanya dalam hal penandatanganan Akta Nikah yang belum dilaksanakan secara sempurna. Hal ini akan dapat dilakukan penandatanganan oleh mempelai pria setelah kemudian ia pulang ke tanah air, agar dapat dijadikan bukti yang sah menurut hokum positif, meskipun Akta Nikah tersebut hanya sebagai bukti admisnistratif, untuk itu pernikahan via teleconference tata caranya juga harus berdasarkan Pasal 8, 10, dan Pasal 11 PP No. 9 tahun 1975.

\section{DAFTAR PUSTAKA}

bin/content.cgi/masail/aula/tahun_2004/ni kah-01. single? seemore $=y$

bin/content.cgi/masail/aula/tahun_2004/ni kah-01. single? seemore $=y$

Budi Putra, Planet Seluler, Tanggerang: Logicom Publications, cet, I, 2004.

Chuzaimah T. Yanggo, dan Hafidz Anshary AZ., Problematika Hukum Islam Kontemporer. Jakarta: Pustaka Firdaus, 1994.

http://ahmad bin hanbal.wordpress.com/2010/06/21/h ukum-menikah-via-internet/

http://searchnetworking.

Techttarget.com/sDefinition/0,,sid7_ gci213111,00.html.

http://tarjihmuhammadiyah.blogspot.com

http://vladamirivanovic.blogspot.com/201 0/05/bm-diniyah-maudluiyahmuktamar-nu-ke-32.html/

http://www.irib.ir/worldservice/melayuRA DIO/kal_sejarah/maret/10maret.htm

Ibn Rushd, Bidayat al-Mujtahid. Mesir: Mustafa al-Babi al-Halabi, 1960.

Ibn Hajar al-'Asqalani. Fath\} al-Bari. Beirut: Dar al-Kitab al-'Arabi, tt.

Idha Apriliyana, Keabsahan Suatu pernikahan melalui Pemanfaatan
Media Telekomunikasi dihubungkan Dengan penetapan pengadilan Agama Jakarta Selatan No. 1751/P/1989 tanggal 20 April 1990 mengenai Sahnya Pernikahan Melalui Telepon, Skripsi sarjana Universitas Pasundan Bandung, 1997.

John Naughton, A Brief History of the Future, editor, Lyndon Saputra, Sejarah Singkat dari Masa ke Masa Depan (Asal Usul Internet), Batam Centre, 2004.

al-Kasani, Ala' al-Din. Badai' al-S\}ana ' $i$ fi Tartib al-Shara' $i$ '. Beirut: Da>r al-Kutub al-'Arabi, 1982.

Lahmuddin Nasution, Pembaharuan Hukum Islam dalam mazhab Syafi'i. Bandung: Remaja Rosdakarya, 2001.

Mahfudz, Sahal. Solusi Problema Umat. Surabaya: Ampel Suci, 2003.

Majalah Majma' al-Fiqh al-Islami, OKI, Periode ke-6, no: 2/1256.

Majalah Varia peradilan, No. 62 Th. VI 1990.

Majalat Majma' al-Figh al-Islami, OKI, Periode ke-6 (no: 2/1256).

Mughniyah, Muh \}ammad Jawad. Fiqih Lima Mazhab. Cet. II. Jakarta: Lentera Basritama, 1996.

al-Qurahdaghi, 'Ali Muh\}y al-Din. Fiqih Digital. Penerjemah Pahruroji S. Yogyakarta: Qanun Prisma Media, 2003.

Rofiq, Ahmad. Hukum Islam di Indonesia. Yogyakarta: Gema Media, 2001.

Republik Indonesia. Undang-undang No. 36 tahun 1999 tentang Telekomunikasi, Kalibening: Pustaka Digital, SMP Alternatif Qaryah Thoyyibah, 2005.

www.inilah.com, Inovasi Portal Berita. Diakses Jumat, 26 Maret 2010, 16:14 WIB.

al-San'ani, Muhammad ibn Isma'il Amir al-Yamani. Subul al-Salam Sharh\} Bulugh al-Maram. Cet. III. Lebanon: Dar al-Kitab al-'Arabi, 1987. 
al-Shafi'i, 'Abdullah Muhammad ibn Idris. al-Umm. Beirut: Dar al-Kutub al-'Arabi, tt.

al-Shatri, Muh\}ammad ibn Ah\}mad ibn 'Umar. Sharh al-Yaqut 'an al-Nafs. Beirut: Dar al-Kutub al-'Arabi, tt.

al-Suwayfi, Sulayman. Hashiyat alBujayrami 'alá al-Khatib. Lebanon: Dar al-Kitab 'Arabi, tt.

Zein, Satria Effendi M. Problematika Hukum Keluarga Islam Kontemporer, Analisis Yurisprudensi dengan Pendeketan Ushuliyah. Jakarta: UIN Jakarta dan Balitbang DEPAG RI, 2004.

al-Zuhayli, Wahbah. al-Figh al-Islami waAdillatuh. Beirut: Dar al-Fikr, 1986. 